\title{
Relationship Between Lumbar Muscle Strength and Proprioception After Fatigue in Men with Chronic Low Back Pain
}

\author{
Kronik Bel Ağrılı Erkeklerde Bitkinlik Sonrası Lomber Kas Gücü ve \\ Propriyosepsiyon Arasındaki ilişki
}

\author{
Bilge Yılmaz, Evren Yaşar, Mehmet Ali Taşkaynatan, Ahmet Salim Göktepe, ilknur Tuğcu, \\ Kamil Yazıcıoglu, Haydar Möhür
}

Türk Silahlı Kuvvetleri Rehabilitasyon Merkezi, GATA, Fiziksel Tıp ve Rehabilitasyon Anabilim Dalı, Ankara, Turkey

\begin{abstract}
Objective: To evaluate the relationship between lumbar position sense and trunk muscle strength, to investigate the effect of fatigue on this relationship, and the effect of fatigue on proprioception in patients with chronic low back pain (CLBP).

Materials and Methods: A cross-sectional study was conducted to determine lumbar position sense and trunk muscle strength in 19 males with low back pain and in 20 healthy controls. After neurological examination every subject was evaluated for repositioning error (RE) with Cybex Norm isokinetic dynamometer using the trunk extension-flexion modular component. Then, every subject underwent a concentric/concentric exercise program including extension and flexion exercises performed actively for 15 times with the velocity of $60^{\circ} /$ second. Finally, the $\mathrm{RE}$ test was repeated.

Results: Differences in RE between the groups were significant before and after fatiguing exercise procedure. After fatigue, changes in RE were found significant in both groups. Differences in flexion peak torque and total work between the groups were significant. Second RE measurement was found to be correlated with flexion peak torque and total work in control group.

Conclusion: The results of this study reveals that flexor muscle strength is significantly lower in patients with CLBP. RE was significantly higher in patients compared to the healthy controls. We found that abdominal muscle strength was moderately correlated with position sense in healthy population after fatigue, whereas there was no correlation in patient group. (Turk J Rheumatol 2010; 25: 68-71)
\end{abstract}

Key words: Chronic low back pain, proprioception, muscle strength, fatigue

Received: 26.08 .2008

Accepted: 05.11.2008

\section{Özet}

Amaç: Kronik bel ağrılı erkek hastalarda lomber pozisyon hissi ve paravertebral kas gücü arasındaki ilișkiyi tanımlamak ve yorgunluğun propriyosepsiyon üzerindeki etkisini ortaya koymak

Yöntem ve Gereçler: Lomber pozisyon hissini (LPH) tanımlamak ve paravertebral kas gücü ile arasındaki ilișkiyi ortaya koymak üzere kronik bel ağrılı 19 erkek hasta ve sağlıklı 20 erkek değerlendirilmeye alındı. Hastaların nörolojik muayenelerini takiben, Cybex Norm İzometrik Dinamometresinin gövde aparatı kullanılarak lomber pozisyon hissi değerlendirildi. Tüm hastalar $60 \%$ sn hızda 15 kez fleksiyon ve ekstansiyon egzersizleri konsantrik/ konsantrik modda uygulandı. Bu uygulamadan hemen sonra lomber pozisyon hissi tekrar değerlendirildi.

Bulgular: LPH, yorgunluk öncesi ve sonrasında gruplararasında istatistiksel olarak anlamlı ölçüde farklıydı. Yorgunluk sonrasında, LPH'deki değișim her iki grupta da anlamlı ölçüde farklıydı. Fleksiyon pik tork ve total work değerlendirilmelerinde anlaml farklılık bulundu. Kontrol grubunda, 2. LPH ölçümleri ile total work ve fleksiyon pik tork arasında anlamlı bir korelasyon bulundu.

Sonuç: Bu çalıșmanın sonuçları kronik bel ağıılı erkek hastalarda fleksör kas gücünün anlamlı ölçüde düsük olduğunu ortaya koydu. LPH, hasta grubunda kontrol grubuna oranla önemli ölçüde azdı. Yorgunluk sonrasında sağlıklı bireylerde pozisyon hissi ile abdominal kas gücü arasında orta derecede bir korelasyon var iken hasta grubunda bu ilișkinin olmadığını bulduk.

(Turk J Rheumatol 2010; 25: 68-71)

Anahtar sözcükler: Kronik bel ağrısı, propriyosepsiyon, kas gücü, yorgunluk

Alındığı Tarih: 26.08.2008 Kabul Tarihi: 05.11.2008

\section{Introduction}

Proprioception is one of the most important mainstays of musculoskeletal rehabilitation and is a term used to describe the complex relations between afferent and efferent pathways that are regulated by mechanoreceptors in the joints (1). Position sense or repositioning error are the most widely used methods to measure proprioception.

In patients with chronic low back pain (CLBP), some structural and functional changes occur in articular and

Address for Correspondence: Dr. Bilge Yılmaz, Türk Silahlı Kuvvetleri Rehabilitasyon Merkezi, GATA, Fiziksel Tıp ve Rehabilitasyon Anabilim Dalı, Ankara, Turkey Phone: t90 3122911607 E-mail: bilgeyilmaztr@hotmail.com 
periarticular structures. Hence, it has been shown that proprioception is also affected in patients with CLBP (2). Patients with CLBP frequently demonstrate difficulty adopting and maintaining a neutral or midrange position of the lumbar spine (3). Proprioceptive deficit may lead to delayed neuromuscular protective reflexes and coordination such that muscle contraction occurs too late to protect the joint from excessive joint movement (2). Moreover, under stress conditions such as mechanical loading or fatigue, the ability to sense a change in lumbar position may be highly affected (4).

Newcomer et al. (5), found that lumbar flexor proprioception is impaired much more than extensor proprioception in patients with CLBP. They postulated that this might be because of the contribution of a wide range of muscles including abdominal, psoas, posterior hip group, and erector spinae and the larger excursion during lumbar flexion which challenges muscles more. In a recent study, the same author reported that rectus abdominis muscle activation pattern was changed in some positions on a force plate in patients with CLBP (6). The results of these studies pointed out that the deterioration in flexor muscle group of lumbar region is more prominent in patients with CLBP.

Although a decrease in strength of trunk muscles can be expected in chronic low back pain, there is still a lack of objective studies investigating the relationship between the changes in strength of trunk muscles and the changes in proprioception. The aim of this study was to evaluate the relationship between lumbar position sense and trunk muscle strength, to investigate the effect of fatigue on this relationship and the effect of fatigue on proprioception in patients with CLBP.

\section{Materials and Methods}

For the patient group, individuals were consecutively selected from a population of young recruits with non radicular low back pain lasting more than 3 months and not radiating below knee level. Healthy subjects who applied for periodic health examination to our outpatient clinic with no complaints were included in control group. They did not have a history low back pain for at least one year. The intensity of low back pain was assessed by 100$\mathrm{mm}$ Visual Analog Scale (VAS) before testing. All volunteers had lumbar flexion of at least $90^{\circ}$ from standing erect position without severe low back pain.

Exclusion criteria for both groups were history of radiculopathy, previous back surgery or a vertebral compression fracture, current lower extremity problems (e.g. atrophy, extremity shortness), any neurologic deficit, symptoms of dizziness, and systemic diseases that can effect proprioception (e.g. diabetes mellitus, polyneuropathy).

After neurological examination every subject was evaluated isokinetically for repositioning error and lumbar paraspinal muscle strength with Cybex Norm isokinetic dynamometer (Lumex, Ronkonkoma, NY) using the trunk extension-flexion modular component. This apparatus which has been used in some studies does not deal with the effect of gravitational forces $(7,8)$. Subjects with eyes and ears covered were placed in this device and their lower limbs were stabilized by tibial and thigh pads. A belt secured the pelvis to limit the use of hip flexors. A shoulder harness and backrest provided anchorage to the moving upper section of the apparatus.

Before testing, subjects performed standardized warmup trials consisted of 6 minutes on an ergometric bicycle followed by a thorough explanation of the test procedure. Isokinetic dynamometer moved the trunk of the participants through flexion with an angular velocity of $1^{\circ} / \mathrm{sec}-$ ond holding a switch in their right hand, it was stopped at $60^{\circ}$ degree and they were told to keep this position in their mind. After that, they were brought back to the neutral position. When the device moved again, they were instructed to press the switch with the right thumb finger as soon as they sensed the right position.

The degree of deviation from $60^{\circ}$ flexed position was calculated as repositioning error (RE). This test was performed two times for each subject. We used the mean values of two measurements to exclude the influence of learning factor that could affect test performance (1 ${ }^{\text {st }} \mathrm{RE}$ Measurement). Then, every subject was joined to the concentric/concentric exercise program including extension and flexion exercises in full range of motion performed actively for 15 times with the velocity of $60^{\circ}$ / second. Immediately after the exercise program, the repositioning error test was repeated (2nd $R E$ Measurement). RE measurements and exercise program were performed consecutively using the same dynamometer without any resting. The isokinetic parameters used for evaluation of muscle strength were total work in joules and peak torque in Newton-meter unit.

\section{Statistical Analysis}

Comparisons between groups were analyzed by Student's t-test. Paired t test was used to analyze withingroup comparisons. Correlations between variables were analyzed using Spearman's correlation test. Statistical analyses were done by using the SPSS v10.0 program.

\section{Results}

There were 19 males in the patient group and 20 males in the control group. All subjects were active persons who were involved in sports activities with irregular intervals. Comparisons between two groups are presented at Table 1. Differences in repositioning error before and after concentric exercise procedure between the groups were statistically significant $(p<0.05)$ (Table 1$)$. After fatigue, changes in repositioning error were found significant in both groups $(p<0.05)$ (Figure 1).

While differences in flexion peak torque and total work between the groups were statistically significant $(p<0.05)$, differences in extension measures were not found significant ( $p>0.05)$. Besides, there were no significant differences in mean peak torque and mean total work between two groups (Table 1). Mean flexion peak torque angle was $51.66 \pm 8.7$ degrees in study group and 
$61.4 \pm 6.9$ degrees in control group. Mean extension peak torque angle was $41 \pm 11$ in study group and $50.5 \pm 8.2$ in control group. These differences were significant $(p<0.05)$.

The correlation between $2^{\text {nd }} \mathrm{RE}$ measurement and flexion torque and total work values were found statistically significant in control group $(p<0.05)$ in contrary to study group $(p>0.05)$. Nevertheless, there was no significant correlation between $2^{\text {nd }} \mathrm{RE}$ measurement and extension test parameters in either group ( $p>0.05$ ) (Table 2). When we deal with the alteration between $1^{\text {st }} \mathrm{RE}$ measurement and $2^{\text {nd }} \mathrm{RE}$ measurement, there was no significant difference between two groups ( $p>0.05)$.

\section{Discussion}

The results of this study revealed that flexor muscle strength is significantly lower in patients with CLBP. The RE was found to be higher in patients with CLBP compared to the healthy controls. Also, there was no relationship between abdominal muscle strength and proprioception in patients with CLBP.

It has been widely reported that patients with low back pain develop a deconditioning syndrome that particularly influences the strength and function of the trunk muscles, with such patients being much weaker than healthy controls (8-11).

Several studies demonstrated that extensor strength is affected more than flexor strength in $\operatorname{CLBP}(12,13)$. Shirado et al. (14), reported that patients with CLBP had greater flexor/extensor ratios than the healthy subjects. However, there are some studies in the literature which supports the notion that involvement of extensor muscles is not more prominent in CLBP. Hultman et al. (15), studied 3 groups of middle-aged men; nonimpaired low back, intermittent LBP and CLBP. In all groups, the ratio of trunk extensor endurance to trunk flexor endurance approximated 3: 1. Similarly, we did not find a significant difference in lumbar extensor muscle strength between the patient and control groups after fatigue in this study. However, the strength of flexor muscles in the patient group was significantly lower than that of the control group. We think that adaptation to disease process in lumbar extensor muscles is better than that of lumbar flexor muscles. A possible explanation for this may be the contribution of wider range of muscles during flexion as it was postulated by Newcomer et al. (5).

In our study, the higher flexor RE of the lumbar region in patients with CLBP compared to the healthy controls is consistent with the results of other authors $(5,16,17)$. Although there are various factors affecting proprioception in CLBP, paraspinal muscles can be considered as a major factor $(18,19)$. Trunk muscle dysfunction may cause alterations in normal afferent input from the affected muscles. On the other hand, proprioceptive impairment may cause different activation patterns and creates new adaptive protective mechanisms. Either being a cause or a result of CLBP, it is an expected outcome.

Before fatigue, the patient group had significantly higher RE than the control group. After fatigue RE was improved in both groups. This improvement seems likely to be due to learning and adaptation to the procedure. On the other hand, our results have indicated that only flexor muscle strength is related with proprioception after fatigue in healthy subjects in contrary to the patient population.

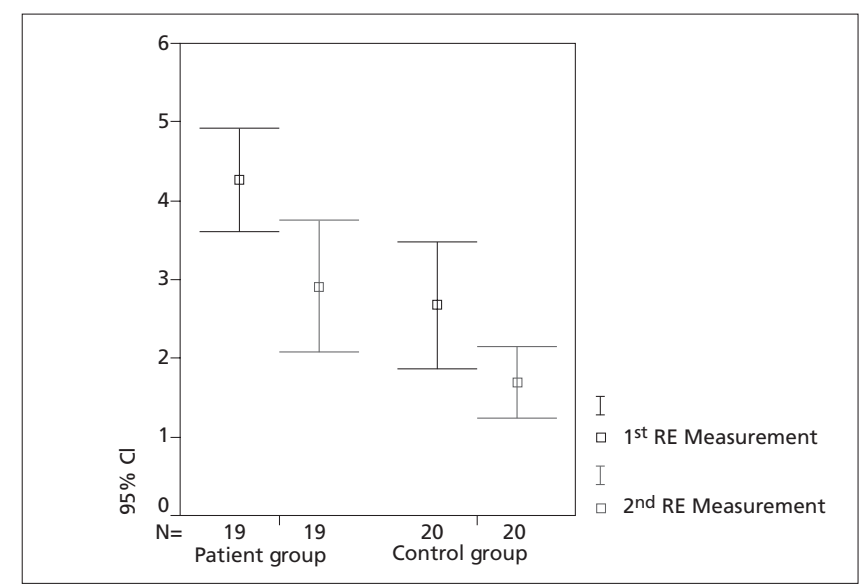

Figure 1. After fatigue, changes in repositioning error in both groups

Table 1. Comparison of demographic characteristics and clinical parameters between study and control groups

\begin{tabular}{|c|c|c|c|}
\hline & $\begin{array}{l}\text { Study group } \\
(n=19)\end{array}$ & $\begin{array}{c}\text { Control group } \\
(n=20)\end{array}$ & p \\
\hline Age (y) & $25.2 \pm 8.2$ & $24.2 \pm 5.6$ & 0.67 \\
\hline $\operatorname{VAS}(\mathrm{mm})$ & $55.2 \pm 13.1 \mathrm{~mm}$ & 0 mm (No pain) & - \\
\hline Body Mass Index $\left(\mathrm{kg} / \mathrm{cm}^{2}\right)$ & $22.64 \pm 0.78$ & $23.26 \pm 0.84$ & 0.58 \\
\hline 1st RE Measurement (degrees) & $4.26 \pm 1.37$ & $2.68 \pm 1.74$ & 0.002 \\
\hline $2^{\text {nd }}$ RE Measurement (degrees) & $2.92 \pm 1.73$ & $1.70 \pm 0.98$ & 0.02 \\
\hline Flexion Peak Torque (Nm) & $134.84 \pm 47.67$ & $180.20 \pm 39.44$ & 0.012 \\
\hline Flexion Total Work (Joule) & $123.97 \pm 52.35$ & $180.45 \pm 37.12$ & 0.001 \\
\hline Extension Peak Torque (Nm) & $108.24 \pm 49.67$ & $118.10 \pm 27.65$ & 0.74 \\
\hline Extension Total Work (Joule) & $100.37 \pm 54.19$ & $120.95 \pm 33.72$ & 0.17 \\
\hline Mean Peak Torque $(\mathrm{Nm})$ & $133.87 \pm 32.60$ & $170.58 \pm 93.35$ & 0.20 \\
\hline Mean Total Work (Joule) & & $135.46 \pm 40.66$ & \\
\hline$(n=18)$ & $135.43 \pm 32.74$ & & 0.65 \\
\hline
\end{tabular}


Table 2. Correlations between repositioning error measurements and isokinetic test parameters

\begin{tabular}{|c|c|c|c|c|c|c|c|}
\hline & & \multirow[t]{2}{*}{ FPT } & FTW & EPT & ETW & MPT & MTW \\
\hline & & & \multicolumn{5}{|c|}{ Correlation Coefficient ( $r$ ) } \\
\hline Study Group & $2^{\text {nd }} \mathrm{RE}$ & -0.059 & -0.346 & -0.181 & -0.184 & 0.109 & 0.067 \\
\hline Control Group & $2^{\text {nd }} \mathrm{RE}$ & $-0.471 *$ & $-0.498 *$ & $-0.476 *$ & -0.377 & -0.069 & -0.186 \\
\hline
\end{tabular}

Flexion requires activation of abdominal, psoas, posterior hip group, and erector spinae muscles and also complex coordination of hip and pelvis (20). Extension is the direction that activates the facet joint mechanoreceptors most http: //gateway.ut.ovid.com/gw1/-82 (21).

In patients with CLBP, a particular muscle activation (gluteal etc.) pattern is inhibited, thus creating abnormal movement of the pelvis and spine leading to further deterioration in CLBP (5). Subsequently, to create an adaptive protective mechanism, an alteration of activation patterns of different muscle groups may be expected. Indeed, the literature showed us that lumbar paraspinal muscle activation patterns are different in patients with CLBP from those of the healthy controls (22). To have an idea about this alteration in activity patterns, we have checked the peak torque angles in both groups. The peak torque angles at both flexion and extension were significantly different between groups.

In a recent meta-analysis, it was shown that most of the studies dealing with the effects of exercise in patients with CLBP consist of abdominal exercise programs (23). However, it is not known how strengthening exercises affect the protective abilities of lumbar spine. Further studies are needed to determine if exercise programs not including specific proprioceptive exercises, affect the relationship between muscle strength and proprioception.

In conclusion, we believe that the imbalance between flexor muscle strength and proprioception may be the key factor to explain the lack of relationship between proprioception and flexor muscle strength after fatigue in CLBP patients. However, this needs to be verified in further studies.

\section{Conflict of Interest}

No conflict of interest is declared by authors.

\section{References}

1. Gandevia SC, McCloskey DI, Burke D. Kinesthetic signals and muscle contraction. Trends Neurosci 1992; 15: 62-5.

2. O'Sullivan PB, Burnett A, Floyd AN, Gadsdon K, Logiudice J, Miller $D$ et al. Lumbar repositioning deficit in a specific low back pain population. Spine 2003; 28: 1074-9.

3. Lam SS, Jull G, Treleaven J. Lumbar spine kinesthesia in patients with low back pain. J Orthop Sports Phys Ther 1999; 29: 294-9.

4. Taimela S, Kankaanpaa M, Luoto S. The effect of lumbar fatigue on the ability to sense a change in lumbar position; a controlled study. Spine 1999; 24: 1322-7.

5. Newcomer KL, Laskowski ER, Yu B, Johnson JC, An KN. Differences in repositioning error among patients with low back pain compared with control subjects. Spine 2000; 25: 2488-93.
6. Newcomer KL, Jacobson TD, Gabriel DA, Larson DR, Brey RH, An KN. Muscle activation patterns in subjects with and without low back pain. Arch Phys Med Rehabil 2002; 83: 816-21.

7. Karatas GK, Gogus F, Meray J. Reliability of isokinetic trunk muscle strength measurement. Am J Phys Med Rehabil 2002; 81: 79-85.

8. Corin G, Strutton PH, McGregor AH. Establishment of a protocol to test fatigue of the trunk muscles.Br J Sports Med 2005; 39: 731-5.

9. Kramer M, Ebert V, Kinzl L, Dehner C, Elbel M, Hartwig E. Surface electromyography of the paravertebral muscles in patients with chronic low back pain. Arch Phys Med Rehabil 2005; 86: 31-6.

10. Verbunt JA, Seelen HA, Vlaeyen JW, van de Heijden GJ, Heuts $\mathrm{PH}$, Pons $\mathrm{K}$, et al. Disuse and deconditioning in chronic low back pain: concepts and hypotheses on contributing mechanisms. Eur J Pain 2003; 7: 9-21.

11. Kaser L, Mannion AF, Rhyner A, Weber E, Dvorak J, Müntener M. Active therapy for chronic low back pain: part 2. Effects on paraspinal muscle cross-sectional area, fiber type size, and distribution. Spine 2001; 26: 909-19

12. Mayer TG, Smith SS, Keeley J, Mooney V. Quantification of lumbar function. Part 2: Sagittal plane trunk strength in chronic low-back pain patients. Spine1985; 10: 765-72.

13. Bayramoglu M, Akman MN, Kilinc S, Cetin N, Yavuz N, Ozker R. Isokinetic measurement of trunk muscle strength in women with chronic low-back pain. Am J Phys Med Rehabil 2001; 80: 650-5.

14. Shirado O, Ito T, Kaneda K, Strax TE. Concentric and eccentric strength of trunk muscles: influence of test postures on strength and characteristics of patients with chronic low-back pain. Arch Phys Med Rehabil 1995; 76: 604-11.

15. Hultman G, Nordin M, Saraste H, Ohlsen H. Body composition, endurance, strength, cross-sectional area, and density of MM erector spinae in men with and without low back pain. J Spinal Disord 1993; 6: 114-23.

16. Gill KP, Callaghan MJ. The measurement of lumbar proprioception in individuals with and without low back pain. Spine 1998; 23: 371-7.

17. Brumagne $S$, Lysens $R$, Spaepen A. Lumbosacral position sense during pelvic tilting in men and women without low back pain: test development and reliability assessment. J Orthop Sports Phys Ther 1999; 29: 345-51.

18. Main CJ, Watson PJ. Psychological aspects of pain. Manual Ther 1999; 4: 203-15.

19. Maffey-Ward L, Jull G, Wellington L. Toward a clinical test of lumbar spine kinesthesia. J Orthop Sports Phys Ther 1996; 24: 354-8.

20. Tan JC, Roux EB, Dunand J, Vischer TL. Role of physical therapy in the management of common low back pain. Baillieres Clin Rheumatol 1992; 6: 629-55.

21. Dreyer SJ, Dreyfuss PH. Low back pain and the zygapophysial (facet) joints. Arch Phys Med Rehabil 1996; 77: 290-300.

22. Reid S, Hazard RG, Fenwick JW. Isokinetic trunk-strength deficits in people with and without low-back pain: a comparative study with consideration of effort. J Spinal Disord 1991; 4: 68-72.

23. Liddle SD, Baxter GD, Gracey JH. Exercise and chronic low back pain: what works? Pain 2004; 107: 176-90. 